BIOMEDICAL AND BIOSOCIAL ANTHROPOLOGY
$\begin{gathered}\text { Official Journal of the International Academy } \\ \text { of Integrative Anthropology } \\ \text { journal homepage: http://bba-journal.com }\end{gathered}$

\title{
Ovarian characteristics in the fetal period: topographic and morphometric parallels
}

\section{Proniaiev D. V., Bulyk R. Ye}

Higher State Educational Establishment of Ukraine "Bukovinian State Medical University", Chernivtsi, Ukraine

\section{ARTICLE INFO}

Received: 21 December 2018

Accepted: 21 January 2019

UDC: $611.651 .013 .018-022.5-053.15$

CORRESPONDING AUTHOR

e-mail: proniaiev@bsmu.edu.ua Proniaiev D. V.

\begin{abstract}
Defects of the urinary system take the 3rd place by their occurrence including $6 \%$ of developmental defects of the female reproductive organs. Therefore modern studies in the field of perinatal anatomy are of a special importance. Objective of the study was to determine age peculiarities in the structure and topography of the fetal ovaries as well as similar and different tendencies in changes of the ovarian morphological parameters of the two groups of fetuses, remote in time. The study was conducted in the two groups of human fetuses, 4-10 months of development, 161.0-500.0 mm of the parietal-calcaneal length. The first group consisting of 35 specimens divided into 7 subgroups according to the month of development (4, 5, 6, 7, 8, 9 and 10), was formed with fetuses died during 2017-2019 years. The second group included specimens of fetuses collected during 1970-1990. The obtained results were statistically processed in the licensed statistical package "Statistica 6.0". The character of distribution for every obtained variation lines, mean values for every sign, standard quadratic deviation, percentile scope of the parameters were evaluated. Reliability of differences in the indices between independent quantitative values was determined by means of Mann-Whitney U-criterion. The conducted study determined that the ascending position of the ovaries in the early fetuses can be considered normal for the given age group, though the topography is indicative of developmental retardation at the late stages of perinatal development. The length of the ovary in both groups increases gradually from the 4th to the 10th month with a certain delay during the 6th month. It might be associated with intensified growth of its parenchyma, and intensive increase of its width and length respectively. The majority of the ovarian parameters of 9-10 month fetuses do not differ reliably, which is indicative of a complete development of the ovarian definite structure at the 9th month of the intrauterine development. Comparison of the parameters of the two groups of fetal specimens, remote in time, is indicative of the fact that in the majority of the parameters they do not differ. Although in modern studies the length of the right ovary in 8-month fetuses, and the length of the left ovary in 7-month fetuses is shorter than that of the archival specimens. Similarly the width of the left ovary in 4-month fetuses appears to be reliably shorter than that of the archival specimens. The thickness of the right ovary of 7 and 10-month modern fetuses is reliably less than that of the appropriate groups of the archival specimens. The thickness of the left ovary of modern fetuses is reliably less than that of the archival specimens during the 10th month. Therefore, a reliable difference was found only in 2 pairs of the parameters included in 42 pairs of the examined morphometric parameters of both groups. It is indicative of inconsiderable changes of these parameters during the period of 27-49 years.

Keywords: ovaries, fetus, anatomy, human.
\end{abstract}

\section{Introduction}

Female reproductive health depends on a normal development of the ovary - one of the most important organs of the reproductive system. Dynamic processes in ovarian topography changes during the perinatal period play an important role as a cause promoting deviations in the sexual development of girls. The causes and the major stages of development of such wide-spread diseases, as ovarian cystic disease, ovarian exhaustion syndrome etc., nowadays is considered to occur during the period of intrauterine development. Therefore, examinations of 
structural peculiarities and organ topography during perinatal period are of special vale. Moreover, the results of such studies form the basis for the development of new and improvement of the existing methods of surgical correction of congenital pathology [2, 13, 17, 20, 21].

Every year according to the available data of medicalgenetic service of the Ministry of Health of Ukraine about 3000 cases of congenital defects of different organs and systems are registered. Defects of the urinary system take the 3 rd place by their occurrence including $6 \%$ of developmental defects of the female reproductive organs. It should be noted that these data are subjective to some extent as a certain percentage of female reproductive pathology is found only when a women is in her fertile age, and it makes the choice of methods and efficacy of treatment complicated [1, 10, 12, 19, 24].

The majority of scientific publications do not contain a comprehensive approach to the study of the issue of perinatal morphogenesis and development of ovarian topography. As a rule, studies are fragmentary and conducted on an inconsiderable amount of objects without consideration of correlative interrelations of the internal female reproductive organs with the adjacent organs at different terms of perinatal period. Therefore, the study within the frame of perinatal anatomy of ovaries is topical and timely [3-6, 8].

Objective of the study was to determine age peculiarities in the structure and topography of the fetal ovaries as well as similar and different tendencies in changes of the ovarian morphological parameters of the two groups of fetuses, remote in time.

\section{Materials and methods}

The study is a fragment of a planned scientific-research work of M.G. Turkevych Department of Human Anatomy and the Department of Anatomy, Clinical Anatomy and Operative Surgery at the Higher State Educational Establishment of Ukraine "Bukovinian State Medical University" (BSMU) "Peculiarities of Morphogenesis and Topography of the Systems and Organs during Prenatal and Postnatal Periods of Human Ontogenesis" (state registration № 0115U002769). The materials of the study are approved by the BSMU Biomedical Ethics Board. It determined that the study was conducted according to the requirements of the Council of Europe Convention for the Protection of Vertebrate Animals used for Experimental and other Scientific Purposes (18.03.1986), World Medical Association Declaration of Helsinki "Ethical principles for medical research involving human subjects" (1964-2013), ICH GCP (1996), EEC Directive № 609 (24.11.1986), the Orders of the Ministry of Health of Ukraine № 690 (23.09.2009), № 944 (14.12.2009), № 616 (03.08.2012).

The study was conducted in the two groups of human fetuses, 4-10 months of development, 161.0-500.0 mm of the parietal-calcaneal length. The first group consisting of 35 specimens divided into 7 subgroups according to the
Table 1. Age of the examined objects.

\begin{tabular}{|c|c|c|c|c|c|c|c|}
\hline \multicolumn{8}{|c|}{ Modern specimens } \\
\hline Months & 4 & 5 & 6 & 7 & 8 & 9 & 10 \\
\hline \multirow{21}{*}{$\begin{array}{l}\text { Parietal- } \\
\text { calcaneal } \\
\text { length }(\mathrm{mm})\end{array}$} & 165.0 & 210.0 & 260.0 & 310.0 & 355.0 & 405.0 & 455.0 \\
\hline & 170.0 & 220.0 & 260.0 & 310.0 & 360.0 & 420.0 & 455.0 \\
\hline & 170.0 & 220.0 & 270.0 & 325.0 & 360.0 & 430.0 & 460.0 \\
\hline & 180.0 & 230.0 & 280.0 & 340.0 & 370.0 & 430.0 & 465.0 \\
\hline & 180.0 & 240.0 & 300.0 & 340.0 & 380.0 & 445.0 & 470.0 \\
\hline & \multicolumn{7}{|c|}{ Archival specimens } \\
\hline & 170.0 & 210.0 & 260.0 & 310.0 & 355.0 & 410.0 & 455.0 \\
\hline & 170.0 & 210.0 & 260.0 & 310.0 & 355.0 & 410.0 & 455.0 \\
\hline & 170.0 & 210.0 & 260.0 & 310.0 & 355.0 & 410.0 & 455.0 \\
\hline & 170.0 & 220.0 & 265.0 & 320.0 & 360.0 & 420.0 & 460.0 \\
\hline & 170.0 & 220.0 & 265.0 & 320.0 & 360.0 & 420.0 & 460.0 \\
\hline & 170.0 & 220.0 & 270.0 & 320.0 & 360.0 & 425.0 & 460.0 \\
\hline & 170.0 & 225.0 & 270.0 & 330.0 & 360.0 & 430.0 & 460.0 \\
\hline & 170.0 & 230.0 & 275.0 & 335.0 & 365.0 & 430.0 & 465.0 \\
\hline & 180.0 & 230.0 & 275.0 & 340.0 & 365.0 & 430.0 & 465.0 \\
\hline & 180.0 & 235.0 & 290.0 & 340.0 & 370.0 & 440.0 & 465.0 \\
\hline & 180.0 & 240.0 & 290.0 & 340.0 & 370.0 & 440.0 & 465.0 \\
\hline & 180.0 & 240.0 & 300.0 & 340.0 & 370.0 & 440.0 & 470.0 \\
\hline & 180.0 & 245.0 & 300.0 & 345.0 & 380.0 & 445.0 & 470.0 \\
\hline & 180.0 & 250.0 & 300.0 & 345.0 & 380.0 & 445.0 & 470.0 \\
\hline & 185.0 & 250.0 & 300.0 & 350.0 & 380.0 & 445.0 & 470.0 \\
\hline
\end{tabular}

month of development $(4,5,6,7,8$, and 10$)$, was formed with fetuses died during 2017-2019 years. They were examined in a prosectorium of Chernivtsi Regional Municipal Medical Institution "Autopsy Bureau" during planned dissections. The second group was formed with fetal specimens taken from the Museum of BSMU Department of Anatomy, Clinical Anatomy and Operative Surgery collected during 1970-1990. The age of fetuses and neonates was determined immediately after they were obtained before fixation by means of measuring the parietalcoccygeal length and parietal-calcaneal length according to the tables by A.A. Zavarzin, A.G. Knorre, B.M. Petten, recommendations issued by B.P. Khvatov, Yu.N. Shapovalov, A.I. Brusilovskyi, L.S. Georgiyevskaya, and G.G. Avtandilov. The age of the examined objects is presented in Table 1. Neutral formaldehyde solution as a fixing solution was chosen because V.I. Proniayev et al [15] indicated it as the one least changing the size of a specimen. First, fetal specimens were measured and then fixed in 5-7\% formaldehyde solution during 2-3 weeks. Then they were kept in 3-5 \% formaldehyde solution.

The obtained results were statistically processed in the licensed statistical package "Statistica 6.0" applying nonparametric assessment methods. The character of distribution for every obtained variation lines, mean values for every sign, standard quadratic deviation, percentile scope of the parameters were evaluated. Reliability of 
differences in the indices between independent quantitative values was determined by means of Mann-Whitney U-criterion $[7,18]$.

\section{Results}

The ovaries in 4-5-month fetuses $(161.0-250.0 \mathrm{~mm}$ of parietal-calcaneal length) are of an elongated triangle regular shape (they do not form folds). Topographic peculiarities of the fetal ovaries on particular examples typical for a certain age period are demonstrated in the Figure 1. The ovaries are located in an ascending position. They closely adjoin to the lateral walls of the rectum. The uterine tubes extend on both sides of the ovaries and adjoin to them: the right uterine tube - to the dorsal side, and the left one - to the ventral. The left ovary touches the loop of the sigmoid by its tubular extremity. The uterine extremity of the left ovary is located on the uterine fundus. In the majority of cases it is concave in shape which is peculiar for this age period. The uterine extremity of the right ovary is immersed into the rectouterine (Douglas') pouch. An ascending position of the ovaries in this case is peculiar for this age group.

The fetus $360 \mathrm{~mm}$ of parietal-calcaneal length is characterized by the ovary with a curved hook-like shape (Fig. 2). The uterine extremity is immersed into the rectouterine (Douglas') pouch. The tubular extremity is curved and touches the sheathing of the right uterine tube. The base and dorsal side adjoin to the iliac vessels and right ureter covered with the parietal layer of the peritoneum of the dorsal abdominal wall. The ovary is of a segmental structure. The uterine and tubular portions are visible separated by a shallow sulcus. It should be noted that segmental structure of the ovaries peculiar for fetuses is found less commonly in adults. In our opinion, it is associated with an increased volume of the parenchyma followed by smoothing the sulci that divide ovaries into the lobes. Thus, division of the ovaries into the lobes is an arbitrary age feature of their structure.

The left ovary has a curved tubular extremity. $2 / 3$ of the ovarian base closely adjoins to the left uterine tube. The dorsal surface touches the parietal peritoneum of the posterior abdominal wall covering ureters and iliac vessels. The ventral surface touches the sigmorectal segment and the sigmoid.

Analyzing the dynamics of changes of the right ovarian length in 4-10-month fetuses from the first group (Fig. $3 \mathrm{~A}$ ), it should be noted that its length is reliably shorter $(p<0.05-$ 0.01 ) in 4-month fetuses than in all the following age periods, except the period of 6 month of development $(p>0.05)$. The length of the right ovary in 5 -month fetuses is shorter than that of the 8-10-month fetuses $(p<0.05-0.01)$, but it is longer than that of 6 -month fetuses $(p<0.05)$. The length of the right ovary of 6-month fetuses is reliably shorter than that of the 5 and $7-10$-month fetuses $(p<0.05-0.01)$. It does not differ from the length of the right ovary in 4-month fetuses $(p>0.05)$. The length of the right ovary in 7 -month

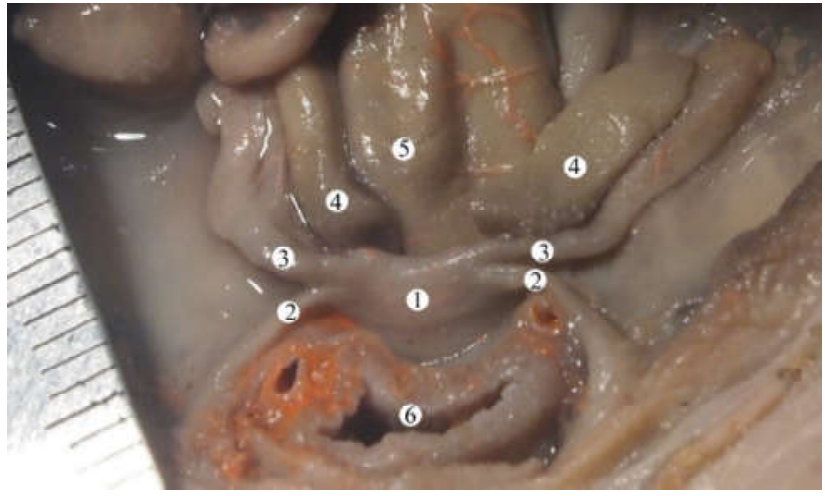

Fig. 1. Internal female reproductive organs of the fetus $270,0 \mathrm{~mm}$ of parietal-calcaneal length. Macrospecimen. Notes: 1 - uterine; 2 - round ligament of uterus; 3 - uterine tubes; 4 - ovaries; 5 - rectum; 6 - urinary bladder.

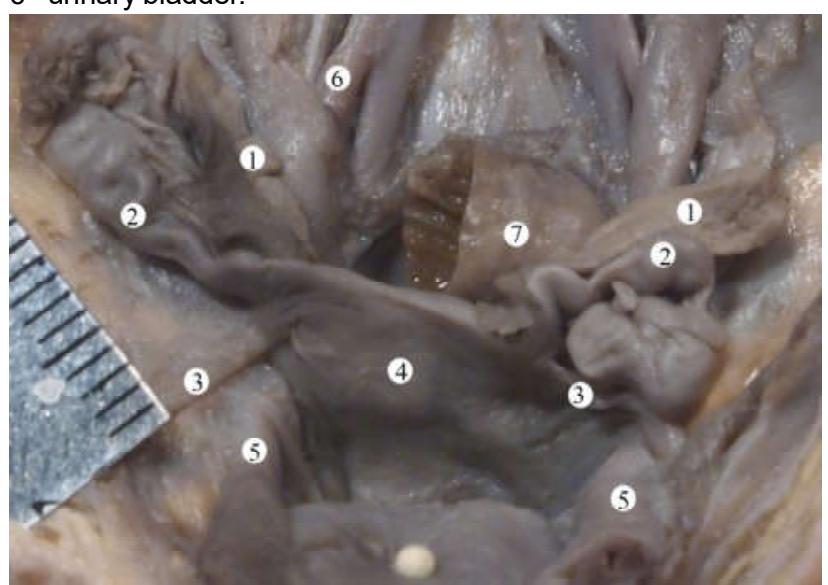

Fig. 2. Internal female reproductive organs of the fetus $270,0 \mathrm{~mm}$ of parietal-calcaneal length. Macrospecimen. Notes: 1 - ovaries; 2 - uterine tubes; 3 - round ligaments of the uterine; 4 - uterine; 5 umbilical arteries; 6 - right ureter; 7 - rectum.

fetuses does not differ reliably from that of the 5 and 8month fetuses $(p>0.05)$. It is reliably longer than the length of the right ovary in the 4 and 6 -month fetuses $(p<0.05)$. The length of the right ovary in the 8-month fetuses is reliably shorter than that of the 9 and 10 -month fetuses $(p<0.05)$. The length of the right ovary of the 9 and 10-month fetuses does not differ reliably $(p<0.05)$. This parameter in the fetuses from the second group (Fig. 3 B) does not differ reliably from that of the first group ( $p>0.05)$ among the 4-7, 9 and 10-month fetuses. Though, it differs reliably in 8month fetuses $(p<0.05)$. It means that the length of the right ovary of modern specimens is shorter than that of the archival ones.

Dynamics of the length of the left ovary from the first group in the fetal period (Fig. $4 \mathrm{~A}$ ) has its certain peculiarities in comparison with the right ovary. This parameter in 4-7month fetuses does not differ reliably $(p>0.05)$, but it is reliably shorter than that of the left ovary in 8-10-month fetuses $(p<0.05-0.01)$. The length of the left ovary in the 58-month fetuses does not undergo much changes either $(p>0.05)$, but it is shorter than that in the 9 and 10-month 

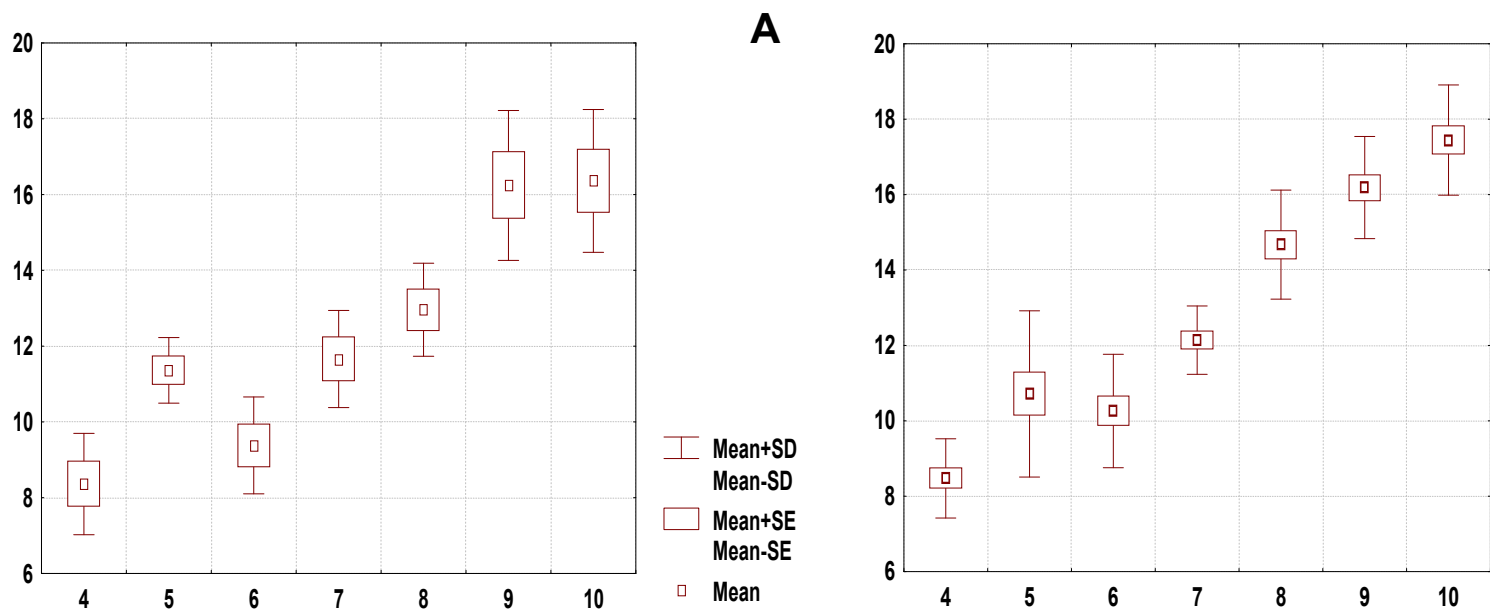

Fig. 3. The length of the right ovary in fetuses from different age groups $(\mathrm{mm})$. Here and further: A - the first group of the study, 20172019; B - the second group, specimens of 1970-1990.
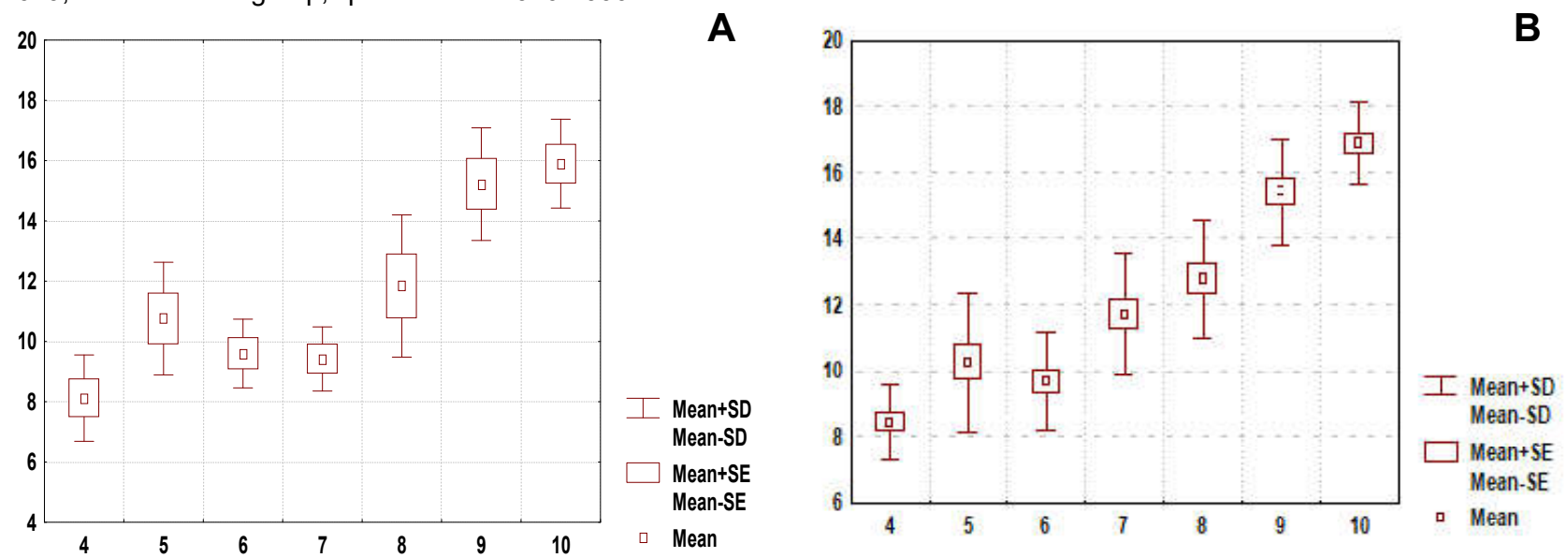

Fig. 4. The length of the left ovary in fetuses of different age groups $(\mathrm{mm})$.
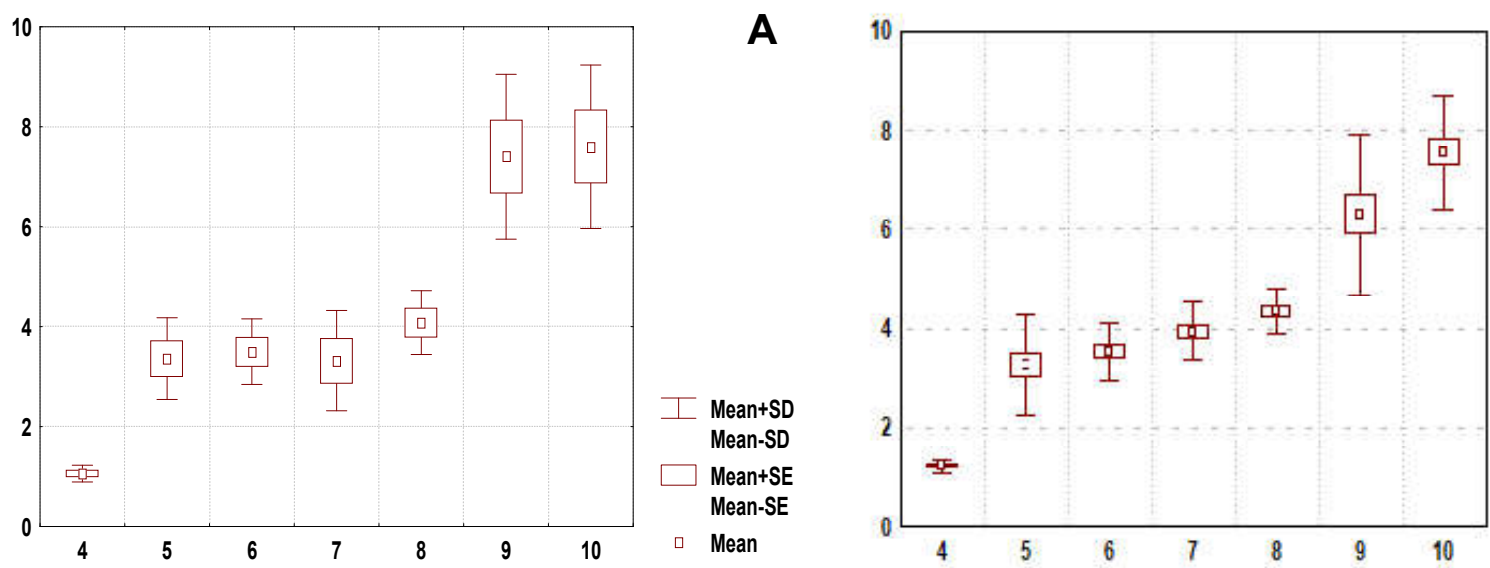

B

Fig. 5. The width of the right ovary in fetuses from different age groups $(\mathrm{mm})$.

fetuses. This parameter of 8-9-month and 9-10-month fetuses does not differ reliably $(p>0.05)$. The length of the left ovary in the 8-month fetuses is reliably longer than that of the 4-7-month fetuses. It is reliably shorter than that of the 9 and 10-month fetuses. The size of the left ovary at this period is reliably longer than in all the previous age groups $(p<0.05-0.01)$. Dynamics of the length of the left ovary in the fetuses from the second group (Fig. $4 \mathrm{~B}$ ) is reliably bigger than that in the 7-month fetuses from the first group $(p<0.05)$. In the rest of the age groups these parameters in the first and second groups do not differ reliably $(p>0.05)$.

The width of the right ovary in the 4-month fetuses is 


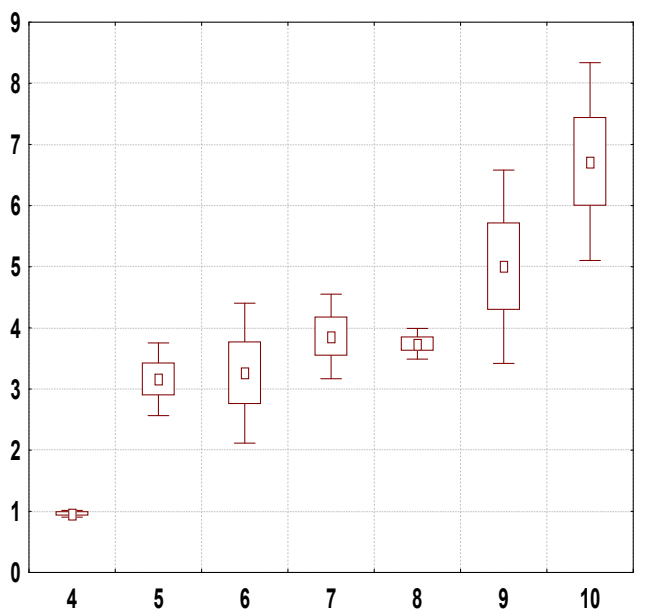

A

B
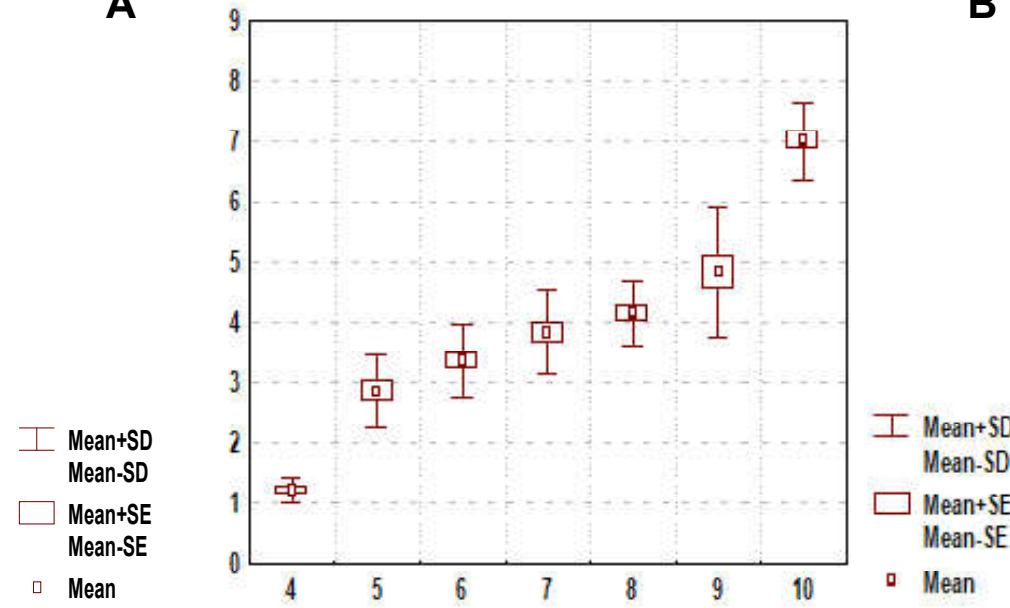

Fig. 6. The width of the left ovary in fetuses from different age groups ( $\mathrm{mm})$.
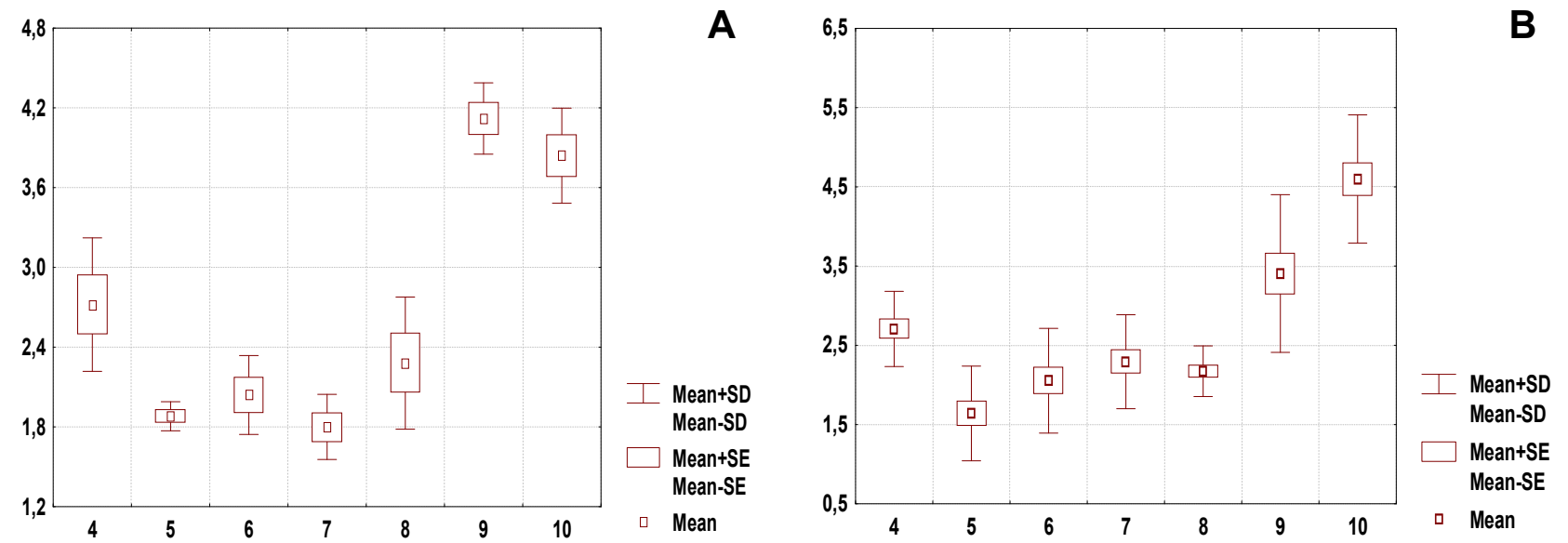

Fig. 7. The thickness of the right ovary in fetuses of different age groups $(\mathrm{mm})$.

reliably shorter than that in all the other age groups $(p<0.01)$ (Fig. 5 A). This parameter in the 5-8-month fetuses does not differ reliably $(p>0.05)$, though it is reliably shorter than that of the $9-10$-month fetuses $(p<0.05)$. Their parameters do not reliably differ $(p>0.05)$. This parameter among the fetuses from the first and second groups does not differ reliably $(p>0.05)$ (Fig. 5 B).

The width of the left ovary in the 4-month fetuses from the first group is reliably shorter than that of all the other age groups $(p<0.01)$ (Fig. 6 A). This parameter in the 5-8month fetuses does not differ reliably similarly to the parameters of the $6-9-$ month fetuses $(p>0.05)$. Though it is reliably shorter than that of the 9-10-month fetuses $(p<0.05)$, which parameters do not differ much $(p>0.05)$. The width of the left ovary in the fetuses from the first and second groups differs reliably between the groups of the 4-month fetuses only $(p<0.05)$ (Fig. 6 B). In the group of modern specimens this parameter is reliably shorter than that of the fetuses from the archival group.

The thickness of the right ovary in the 4-month fetuses from the first group is reliably less than that of the 9 and 10month fetuses $(p<0.05-0.01)$ (Fig. 7 A). Though, it is reliably bigger than that of the 5 and 7 -month fetuses $(p<0.01)$. It coincides with the thickness of the right ovary in the 6 and 8 -month fetuses $(p>0.05)$. This parameter in the 5-8-month fetuses does not differ reliably $(p>0.05)$. It is reliably less than that of the 9 and 10-month fetuses. There was no reliable difference found between their parameters $(p>0.05)$. A reliable difference between the thickness parameters of the right ovary of fetuses in all the age periods between the fetuses from $A$ and $B$ groups was found in the 7 and 20-month fetuses only. In fetuses from A group the thickness of the right ovary is reliably less than that of $B$ group in the 7 and 10-month fetuses (Fig. 7 B).

The thickness of the left ovary in the 4-month fetuses from the first group (Fig. $8 \mathrm{~A}$ ) is reliably shorter than that of the 9 and 10 -month fetuses $(p<0.01)$, but it is reliably bigger than that in the 5-month fetuses $(p<0.05)$, and it coincides with the thickness of the right ovary in the 6-8-month fetuses $(p>0.05)$. This parameter in the 5-8-month fetuses does not differ reliably $(p>0.05)$. It is reliably less than that of the 9 and 10-month fetuses which parameters do not differ reliably $(p>0.05)$. A reliable difference between the thickness parameters of the right ovary in all the age periods between 

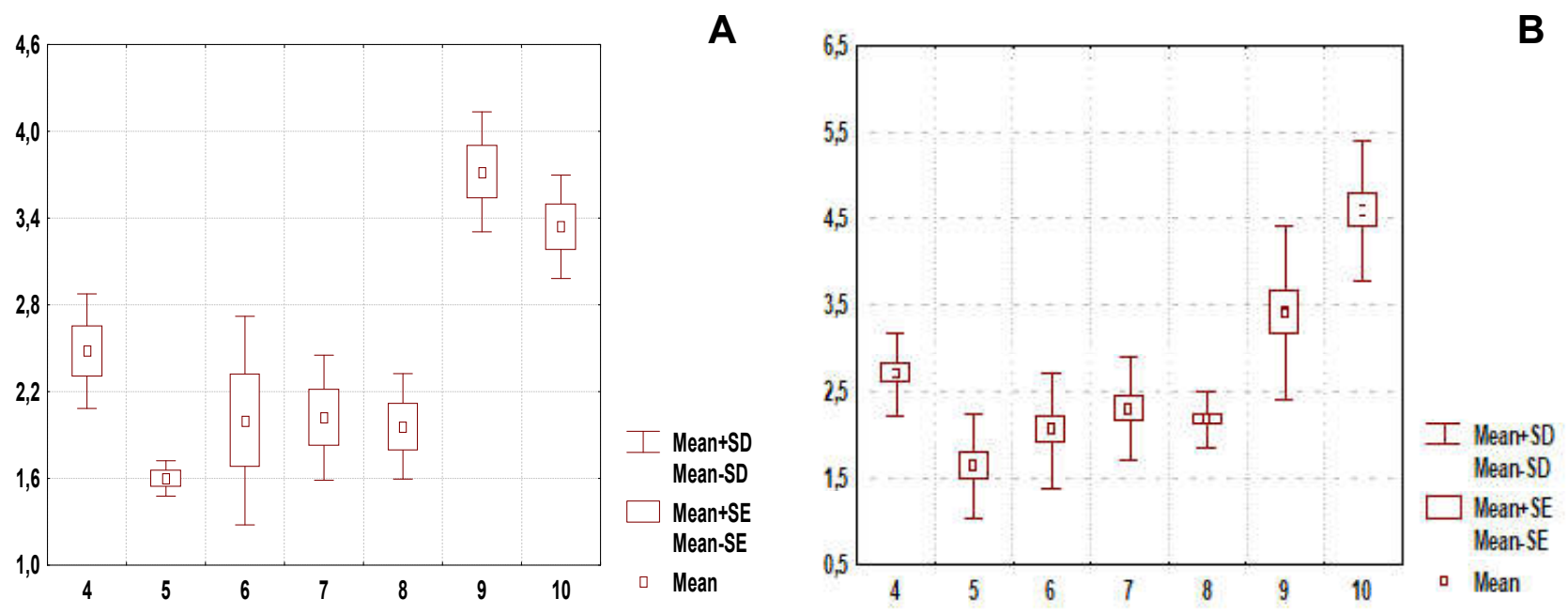

Fig. 8. Thickness of the left ovary of fetuses from different age groups $(\mathrm{mm})$.

the fetuses from $A$ and $B$ groups was found in the 10-month fetuses only. In fetuses from A group the thickness of the right ovary is reliably less than that of $B$ group in the 10 month fetuses (Fig. 8 B).

\section{Discussion}

As the result of examination of the topographic ovarian dynamics in fetuses we have found that during the fetal period ovaries can be in the ascending and descending position (immersed in the rectouterine (Douglas') pouch). The ascending position, when the ovaries can reach the caecum and descending colon (the right and left respectively), is peculiar for the 4-7-month fetuses. Often the ovaries are located on both sides of the rectum and adjoin it closely, immersing by their tubular extremities between the loops of the small intestines. Such topographicanatomical peculiarities can be considered standard for the fetuses of the given age group. Though they can be indicative of developmental retardation at the late stages of the perinatal development, which is not mentioned in the works of certain researchers [9, 14, 16, 19, 23, 25].

In the majority of cases in the 8-month fetuses the ovaries are localized in the cavity of the minor pelvis on the level of the uterine fundus. In late fetuses (9-10 months) and neonates both ovaries occupy the position close to the definite one - parallel to the uterine fundus in the cavity of the minor pelvis, or one of the ovaries remains immersed in the rectouterine (Douglas') pouch.

During the last months of the intrauterine development ovarian topography changes: their position changes from the ascending to the horizontal one. The position in the rectouterine (Douglas') pouch should not be considered peculiar for the definite form, but this position if peculiar for the majority of the late fetuses. Ovarian shape transforms from the elongated triangle to elongated oval. Their segmental structure disappears. To the end of the fetal period the ovarian position changes concerning the uterine tubes from the parallel one at the 8-month period to the perpendicular one at the 10th month.

Analysis of reliable changes of the ovarian morphometric parameters in fetuses by means of MannWhitney $U$-criterion was indicative of the fact that the length of ovaries in both groups increases gradually from the 4th to the 10th months with an inconsiderable retardation at the 6th month. It might be associated with intensified growth of its parenchyma and intensive increase of its width and thickness respectively. The majority of ovarian parameters in the 9-10-month fetuses do not differ reliably, which is indicative of a complete formation of a definite structure of the ovaries at the 9th month of the intrauterine development. Comparison of the parameters of the fetal specimens in the two groups, remote in time, indicates that in the majority of parameters the values do not differ, though in 8-month fetuses the length of the right ovary and in 7-month fetuses the length of the left ovary in modern studies is less than that in the archival specimens. Similarly the width of the left ovary in modern 4-month fetuses is reliably shorter than that of the archival specimens. The thickness of the right ovary in the 7 and 10-month modern fetuses is reliably less than that in the appropriate groups of the archival specimens. The thickness of the left ovary of modern fetuses is reliably less than that of the archival specimens at the 10 th month.

\section{Conclusions}

1. An ascending position, when ovaries can reach the caecum and descending colon (the right and left ovary respectively), is peculiar for the 4-7-month fetuses. It is associated with arcuate or vallate uterus. Such topographicanatomical peculiarities can be considered standard for fetuses of the given age group, though they are indicative of developmental retardation at the late stages of the perinatal development. In the majority of cases ovaries in the 8-10-months occupy a descending position.

2. Morphometric parameters in the group of modern specimens are the following: the length of the right ovary in 
the 8-month fetuses and the left ovary in the 7-month fetuses, the width of the left ovary in the 4-month fetuses, the thickness of the right ovary in the 7 and 10-month

\section{References}

[1]Atici. A., Yilmaz, E., Karaman. A., Apaydin. S., \& Afsarlar, Č. E. (2017). Tuba-ovarian auto-amputation caused by ovarian teratoma in an adolescent girl. The Turkish Journal of Pediatrics, 59(1), 90-92. doi: 10.24953/turkjped.2017.01.017

[2] Bardo, D. M., Black, M., Schenk, K., \& Zaritzky, M. F. (2009). Location of the ovaries in girls from newborn to 18 years of age: reconsidering ovarian shielding. Pediatric Radiology, 39(3), 253-259. doi: 10.1007/s00247-008-1094-4

[3] Chen, S., Li, R., Zhang, X., Lu, L., Li, J., Pan, H., \& Zhu, H. (2018). Combined Ovarian and Adrenal Venous Sampling in the Localization of Adrenocorticotropic Hormone-Independent Ectopic Cushing Syndrome. J Clin Endocrinol Metab., 103(3), 803-808. doi: 10.1210/jc.2017-01977

[4] Const?ncio, C., Pagani, B. T., Azevedo, R. M. G., Grion, D. P., Marques, L., \& Kinoshita, A. (2018). Effect of ovariectomy in bone structure of mandibular condyle. Acta Cir Bras., 32(10), 843-852. doi: 10.1590/s0102-865020170100000006

[5] Dasgupta, R., Renaud, E., Goldin, A. B., Baird, R., Cameron, D. B., Arnold M. A., ... Downard, C. D. (2018). Ovarian torsion in pediatric and adolescent patients: A systematic review. $J$ Pediatr Surg., 53(7), 1387-1391. doi: 10.1016/ j.jpedsurg.2017.10.053

[6] Garrido, M. P., Fernandois, D., Venegas, M., \& Paredes, A. H. (2018) Effects of sympathectomy on ovarian follicular development and steroid secretion. Reproduction, 155(2), 173-181. doi: 10.1530/REP-17-0318

[7] George, C., \& Berge, L. R. (2002). Hypothesis Testing. Statistical Inference. Second Edition. Pacific Grove, CA: Duxbury.

[8] Kitai, S., Kiyokawa, T., Tanaka, Y. O., Onoue, K., Takahashi, H., Saitou, M., ... Fukuda, K. (2018). MRI findings for primary fallopian tube cancer: correlation with pathological findings. Jpn J Radiol., 36(2), 134-141. doi: 10.1007/s11604-017-07050

[9] Lin, D. I., Chudnovsky, Y., Duggan, B., Zajchowski, D., Greenbowe, J., Ross, J. S., ... Elvin. J. A. (2017). Comprehensive genomic profiling reveals inactivating SMARCA4 mutations and low tumor mutational burden in small cell carcinoma of the ovary, hypercalcemic-type. Gynecol Oncol., 147(3), 626-633. doi: 10.1016/j.ygyno.2017.09.031

[10] Luciano A. M., \& Sirard M. A. (2018). Successful in vitro maturation of oocytes: a matter of follicular differentiation. Biology of Reproduction, 98(2), 162-169. doi: 10.1093/biolre/ iox149

[11] Malisic, E., Susnjar, S., Milovanovic, J., Todorovic-Rakovic, N., \& Kesic, V. (2018). Assessment of ovarian function after chemotherapy in women with early and locally advanced breast cancer from Serbia. Arch Gynecol Obstet., 297(2), 495-503. doi: 10.1007/s00404-017-4581-8

[12] Marchuk, V. F. (2007). Ontogenetic transformations of ovaries in the prenatal period of human development. Morphology, fetuses, and the left ovary at the 10th month are reliably less than those in the group of the archival specimens.

\section{1(7), 62-69}

[13] Outwater, E. K., \& Mitchell, D. G. (1996). Normal ovaries and functional cysts: MR appearance. Radiology, 198(2), 397402.

[14] Pascual, M. A., Graupera, B., Pedrero, C., Rodriguez, I., Ajossa, S., Guerriero, S., \& Alcázar, J. L. (2017). Long-term Results for Expectant Management of Ultrasonographically Diagnosed Benign Ovarian Teratomas. Obstet Gynecol., 130(6), 12441250. doi: 10.1097/AOG.0000000000002327

[15] Proniaiev, V. I., Svystoniuk, I. U., \& Akhtemiichuk, Yu. T. (1995). Changes of embryonic length depending on their age, kind and concentration of fixators. Theses published in the materials of the I International Congress on Integrative Anthropology, Ternopil (p. 277-278). Ternopil: [w.p].

[16] Regan, S. L. P., Knight, P. G., Yovich, J. L., Stanger, J. D., Leung, Y., Arfuso, F., ... Dharmarajan, A. (2018). The effect of ovarian reserve and receptor signalling on granulosa cell apoptosis during human follicle development. $\mathrm{Mol} \mathrm{Ce} / \mathrm{l}$ Endocrinol., 470, 219-227. doi: 10.1016/j.mce.2017.11.002

[17] Saksouk, F. A., \& Johnson, S. C. (2004). Recognition of the ovaries and ovarian origin of pelvic masses with CT. Radiographics, 1, 133-146.

[18] Shelamova, M. A., Insarova, N. I., \& Leshchenko, V. H. (2010). Statistical analysis of medical-biological data applying Excel program. Educational-methodiccal manual. Minsk: BSMU.

[19] Sulak, O., Malas, M. A., Esen, K., Cetin, E., \& Tagil, S. M. (2006). Size and location of the fetal human ovary. Fetal Diagnosis and Therapy, 21(1), 26-33.

[20] Togashi, K. (2003). MR imaging of the ovaries: normal appearance and benign disease. Radiologic Clinics of North America, 41(4), 799-811.

[21] Venturoli, S., Porcu, E., Fabbri, R., Paradisi, R., Orsini, L. F, \& Flamigni, C. (1984). Ovaries and menstrual cycles in adolescence. Gynecologic and Obstetric Investigation, 17(4), 219-222.

[22] Yalcin, I., Meydanli, M. M., Turan. A. T., Taskin, S., Sari, M. E., Gungor, T., ... Ayhan, A. (2018). Carcinosarcoma of the ovary compared to ovarian high-grade serous carcinoma: impact of optimal cytoreduction and standard adjuvant treatment. Int $J$ Clin Oncol., 23(2), 329-337. doi: 10.1007/s10147-017-1215$x$

[23] Young, R. H. (2018). Ovarian sex cord-stromal tumours and their mimics. Pathology, 50(1), 5-15. doi: 10.1016/ j.pathol.2017.09.007

[24] Zenkina, V. G. (2014). Morphological features of ovarian fetuses and infants. Fundamental studies, 3(7), 504-508.

[25] Zhao, D., Qu, Q., Dai, H., Liu, Y., Jiang, L., Huang, X., \& Hao, C. (2018). Effects of hypoxia-inducible factor-1 $\alpha$ on endometrial receptivity of women with polycystic ovary syndrome. Mol Med Rep., 17(1), 414-421. doi: 10.3892/mmr.2017.7890

\section{ХАРАКТЕРИСТИКА ЯЄЧНИКІВ У ПЛОДОВОМУ ПЕРІОДІ: ТОПОГРАФІЧНІ ТА МОРФОМЕТРИЧНІ ПАРАЛЕЛІ}

\section{Проняєе Д. В., Булик Р. Є.}

Вади сечостатевої системи посідають 3-тє місце за частотою виникнення. Серед них вади розвитку жіночих статевих органів становлять до 6 \%. Саме тому дослідження перинатальної анатомії нині набуває особливо важливого значення. Мета роботи - встановити вікові особливості будови та топографії яєчників плодів, а також спільні та відмінні тенденції змін морфологічних параметрів яєчників двох груп плодів віддалених у часі. Дослідження проведені на двох групах плодів людини 4-10 місяців розвитку - 161,0-500,0 мм тім'яно-п'яткової довжини. Перша група - 35 препаратів, розділених на 7 
підгруп відповідно місяцям розвитку (4, 5, 6, 7, 8, 9 і 10), була сформована з плодів, що померли впродовж 2017-2019 рр. Друга група була сформована з препаратів плодів, що були зібрані впродовж 1970-1990 рр. Статистичний аналіз отриманих результатів проведений у ліцензійному статистичному пакеті "Statistica 6.0". Проведена оцінка характеру розподілів для кожного з отриманих варіаційних рядів, визначені середні для кожної ознаки, що вивчається, стандартне квадратичне відхилення, процентильний розмах показників. Достовірність різниці значень між незалежними кількісними величинами визначали за допомогою U-критерія Мана-Уітні. В результаті проведених досліджень встановлено, що висхідне положення яєчників ранніх плодів можна вважати нормою для даної вікової групи, проте така топографрія свідчить про затримку розвитку на пізніх етапах перинатального розвитку. Довжина яєчників двох груп поступово збільшується з 4 по 10 місяць, з деякою затримкою росту на 6 місяці, що імовірно пов'язано з інтенсифрікацією розростання їх паренхіми і відповідно інтенсивного збільшення їх ширини та товщини. Більшість параметрів яєчника плодів 9-10 місяців достовірно не різняться, що свідчить про завершення становлення дефрінітивної будови яєчників на 9 місяці внутрішньоутробного розвитку. Порівняння параметрів двох розведених (віддалених) у часі груп препаратів плодів вказує на те, що у переважній більшості показників данні не різняться, проте у плодів 8 місяця довжина правого яєчника і 7 місяця довжина лівого яєчника у сучасних дослідженнях менша ніж у архівних препаратів. Так само ширина лівого яєчника сучасних плодів 4 місяия достовірно менша за таку архівних препаратів. Товщина правого яєчника плодів 7 та 10 місяців сучасних плодів достовірно менша, ніж у відповідних групах архівних препаратів. Товщина лівого яєчника сучасних плодів достовірно менша за таку архівних препаратів на 10 місяці. Отже, з 42 пар досліджених морфометричних параметрів двох груп плодів, достовірну відмінність виявили лише у 2 парах параметрів, що свідчить про незначні зміни цих параметрів впродовж 27-49 років.

Ключові слова: яєчники, плід, анатомія, людина.

\section{ХАРАКТЕРИСТИКА ЯИЧНИКОВ В ПЛОДНОМ ПЕРИОДЕ: ТОПОГРАФИЧЕСКИЕ И МОРФОМЕТРИЧЕСКИЕ ПАРАЛЛЕЛИ Проняев Д. В., БулыК Р. Е.}

Пороки мочеполовой системы занимают 3-е место по частоте возникновения. Среди них, пороки развития женских половых органов составляют до $6 \%$. Именно поэтому исследования перинатальной анатомии сейчас приобретает особенно важное значение. Цель работы - установить возрастные особенности строения и топографрии яичников плодов, а также общие и отличительные тенденции изменения морфологических параметров яичников двух отдаленных во времени групп плодов. Исследования проведены на двух группах плодов человека 4-10 месяцев развития - 161,0-500,0 мм теменнопяточной длины. Первая группа - 35 препаратов, разделенных на 7 подгрупп соответственно месяцам развития (4, 5, 6, 7, 8, 9 и 10), была сформирована из плодов, что умерли в течении 2017-2019 г2. Вторая группа была сформирована из препаратов плодов, собранных в течении 1970-1990 ге. Статистический анализ полученных результатов проведен в лицензионном статистическом пакете "Statistica 6.0". Проведена оценка характера распределений для каждого из полученных вариационных рядов, определены средние для каждого изучаемого признака, стандартное квадратическое отклонение, процентильный размах показателей. Достоверность различий значений между независимыми количественными величинами определяли с помощью U-критерия Мана-Уитни. В результате проведенных исследований установлено, что восходящее положение яичников ранних плодов можно считать нормой для данной возрастной группы, однако такая топографрия свидетельствует о задержке развития на поздних этапах перинатального развития. Длина яичников двух групп постепенно увеличивается с 4 по 10 месяц, с некоторой задержкой роста на 6 месяце, предположительно связано с интенсификацией разрастания их паренхимы и соответственно интенсивного увеличения их ширины и толщины. Большинство параметров яичника плодов 9-10 месяцев достоверно не различались, что свидетельствует о завершении становления дефринитивного строения яичников на 9 месяце внутриутробного развития. Сравнение параметров двух разведенных (удаленных) во времени групп препаратов плодов указывает на то, что в подавляющем большинстве показателей данные не различались, однако у плодов 8 месяца длина правого яичника и 7 месяца - длина левого яичника в современных исследованиях меньше чем у архивных препаратов. Также ширина левого яичника современных плодов 4 месяца достоверно меньше, чем у архивных препаратов. Толщина правого яичника плодов 7 и 10 месяцев современных плодов достоверно меньше, чем у соответствующих группах архивных препаратов. Толщина левого яичника современных плодов достоверно меньще такую архивных препаратов на 10 месяце. Итак, из 42 пар исследованных морфометрических параметров двух групп плодов, достоверное отличие обнаружили только в 2 парах параметров, что свидетельствует о незначительных изменениях этих параметров в течение 27-49 лет.

Ключевые слова: яичники, плод, анатомия, человек. 